\title{
AS CONSTITUIÇÕES SUBNACIONAIS E DIREITOS FUNDAMENTAIS NAS FEDERAÇÕES
}

\section{SUBNATIONAL CONSTITUTIONS AND FUNDAMENTAL RIGHTS IN FEDERATIONS}

José Adércio Leite Sampaio ${ }^{1}$

\section{Resumo}

As federações diferenciam-se entre si quanto ao espaço de autonomia que as suas Constituições deixam aos textos constitucionais das unidades subnacionais, influenciando o nível de proteção normativa dos direitos fundamentais no âmbito do constitucionalismo subnacional. Naqueles em que é deixado um espaço maior ao trabalho constituinte, as declarações de direitos subnacionais tendem a ser mais detalhadas e mais inovadoras do que a existente na Constituição federal. Os direitos sociais, a proteção ambiental e os direitos das minorias estão mais presentes naquelas do que nesta. No Brasil, as Constituições estaduais tendem a detalhar os direitos sociais reconhecidos na Constituição federal, bem como a defesa do meio ambiente, dos direitos sexuais e reprodutivos da mulher, dos afro-brasileiros e de outras minorias. A efetividade dessa proteção, no entanto, é polêmica no Brasil e em outros Estados federais.

Palavras-chave: Estado federal; Constitucionalismo subnacional; Direitos fundamentais

\section{Abstract}

Federations differ among themselves in terms of the autonomy space that their constitutions leave to the constitutional texts of subnational units, influencing the level of normative protection of fundamental rights within the framework of subnational constitutionalism. In those where more space is left for constituent labor, subnational declarations of rights tend to be more detailed and more innovative than that one in the federal Constitution. Social rights, environmental protection and the rights of minorities are more present in those than in this one. In Brazil, the state constitutions tend to detail the social rights recognized in the federal constitution, as well as the defense of the environment, the sexual and reproductive rights of

\footnotetext{
1 Doutor e Mestre em Direito pela Universidade Federal de Minas Gerais. Professor da Pontifícia Universidade Católica de Minas Gerais e da Escola Superior Dom Helder Câmara. Procurador da República. E-mail: joseadercio.contato@gmail.com
} 
women, Afro-Brazilians and other minorities. The effectiveness of this protection, however, is controversial as in Brazil as in other federations.

Keywords: Federal state; Subnational constitutionalism; Fundamental rights

\section{INTRODUÇÃO}

A literatura constitucional e política costuma diferençar a federação das outras formas de Estado pela competência constitucional que possuem as entidades subnacionais, especialmente os extratos de segundo nível (estados-membros, cantões, comunidades, regiões, dentre outros nomes por que são designados). Embora definidas e, portanto, limitadas pela Constituição federal, elas não dependeriam da vontade do legislador federal ordinário (PRÉLOT, 1972, p. 235 ss, 252; FAVOREU, 2006, p. 433). As limitações impostas pelo texto federal variam consideravelmente de um para outro Estado federal. De toda forma, é nos domínios da federação que, pelo menos, em tese, mais se pode falar em "constitucionalismo subnacional", pois se, é nela, que mais bem se apresenta a autonomia constitucional das unidades federativas, é de se esperar que mais se tenha espaço de desenvolvimento dos elementos que caracterizam o ideário do constitucionalismo de limitação de poder e garantia de direitos fundamentais (SAMPAIO, 2002; 2013).

Os direitos fundamentais são o centro ou, pelo menos, um dos principais eixos do constitucionalismo (SAMPAIO, 2013; 2015). Seu reconhecimento formal pelos Estados constitucionais é a regra, embora existam exceções notáveis. A Austrália, por exemplo, um Estado constitucional e federal, não possui uma declaração de direitos, preferindo-se a força das tradições dos direitos da Common Law. Há uma Constituição formal orgânica e uma Constituição material de direitos (SAUNDERS, 1999). Em sendo regra, deve-se analisar que lugar tais direitos ocupam no temário constituinte subnacional nas federações. É esse o objeto do presente artigo. Por meio do estudo comparado e de revisão bibliográfica, procura-se identificar como os textos constitucionais das unidades subnacionais tratam o assunto.

\section{CONSTITUCIONALISMO SUBNACIONAL NOS ESTADOS FEDERAIS}


O "constitucionalismo subnacional" é definido como uma ideologia e um conjunto de norma constitucionais que promovem os direitos fundamentais e a separação de poderes na unidades político-territoriais que se situam, sobretudo, imediatamente abaixo do governo nacional (GARDNER, 2007, p. 3; MARSHFIELD, 2011, p. 1153). É de se esperar que nas federações, ele seja mais desenvolvido, em virtude de ser nelas em que as unidades subnacionais, especialmente de segundo nível como estados-membros, Länder ou cantões, possuem autonomia constitucional. (ELAZAR, 1991, p. xv; STEPAN, 1998; HORTA, 2010, p. 329330). É nelas que a Constituição federal - e não o legislador ordinário - prevê sua existência e os espaços que the são deixados, o que não sucede, por exemplo com os Estados unitários e descentralizados (PRÉLOT, 1972, p. 235 ss, 252; BADÍA, 1976; FAVOREU, 2006, p. 433)².

Os Estados que se autoproclamam federais se dividem em dois grupos: os que preveem a elaboração de uma Constituição subnacional e os que a proíbem. Sob o que se disse no parágrafo anterior, os "proibicionistas" não poderiam ser, por definição, federais. Para alguns autores, no entanto, haveria mais de um critério de caracterização das federações, sendo a autonomia constitucional apenas um deles ${ }^{3}$. A participação das unidades subnacionais na formação de vontade nacional seria, de regra, mais importante (LE FUR, 1896, p. 673-674). Não se visa discutir esse tema aqui, pois, mesmo que se excluíssem os autoproclamados federais sem autonomia constitucional subnacional, haveria um grupo significativo de Estados que a preveem, merecendo a atenção. Sem embargo, dentro dos limites estreitos deste estudo, poder-se-á valer de alguns exemplos apresentados por esse grupo, pela autoproclamação e peculiaridades que alguns apresentam. A Índia, por exemplo, admite que apenas Caxemira possua uma Constituição (Secs. 3, 168-212).

Entre os sistemas que preveem expressamente a autonomia constitucional subnacional, há diferenças importantes. Há, por exemplo, os que "obrigam" e os que "facultam" a elaboração do texto constitucional pelas unidades subnacionais. O Brasil é um exemplo dos que impõem um dever de autoconstituição. O Art. 25 da Constituição federal reconhece a

\footnotetext{
2 Distinção assumida pela jurisprudência do Tribunal Constitucional da Itália (2007) e da Espanha. Se, em 2007, chegou o TC espanhol a considerar que os estatutos das autonomias eram produto de um procedimento "constituinte" complexo, envolvendo a comunidade autônoma e o Estado, compondo o "bloco de constitucionalidade"; em 2010, considerou-os "leis orgânicas" se a hierarquia necessária a integrar aquele bloco (ESPANHA, 2007 e 2010). Na Itália, a situação seria a mesma: os estatutos não seriam Constituições: DELLEDONE; MARTINICO, 2009.

${ }^{3}$ São eles Comores, os Emirados Árabes Unidos, Nepal, Paquistão, a Índia, com exceção da Caxemira, (Secs. 3, 168-212) e a Nigéria (ELAZAR, 1982, p. 9, 178).
} 
autonomia constitucional dos Estados-membros; e o Art. 11 do ADCT estabelece o prazo de um ano, contado de 5 de outubro de 1988, para as assembleias legislativas estaduais elaborarem a Constituição de seus Estados (BRASIL, 1988). ${ }^{4}$ Estão com o Brasil, a Alemanha (art. 28(1)), a Argentina (arts. 5 e 123), a Austrália (sec. 106), a Áustria (art. 99 (1)), os Estados Unidos (art. IV, § 3, cl. 1), a Etiópia (art. 52(2)(b)), o Iraque (art. 116), o México (arts. 115(1(2)), 116 (VIII) e (IX), v.g.), a Suíça (art. 51(1)), o Sudão (art. 178(1)), o Sudão do Sul (art. 164(1)) e a Venezuela (art. 164(1)). A autonomia constitucional é, portanto, um poder-dever. Noutros Estados, prevê-se uma faculdade às unidades subnacionais. Estão, entre eles, a África do Sul (§ 142), a BósniaHerzegovina (art. III(2)(a)), o Canadá (secs. 58-90; Const. 1867, e sec. 45, CA 1982), a Malásia (art. 71) e, em certa medida, a Rússia (art. 66(1)). ${ }^{5}$

Outra diferença importante encontrada nos sistemas federais, em que há o reconhecimento expresso da autonomia constitucional, é o espaço deixado ao exercício dessa autonomia. Há Constituições federais que praticamente esgotam o temário do constituinte subnacional, enquanto outros estabelecem apenas princípios gerais de organização. Entre os extremos, há uma graduação significativa (MARSHFIELD, 2011, p. 1160-1161). Nos Estados Unidos, preordena-se pouco. No Brasil, muito. A África do Sul se aproxima do Brasil na preordenação, mas cria um sistema de controle da produção constituinte que acaba por inibi-la (WATTS, 1999; MARSHFIELD, 2008). Trata-se de uma característica associada a processos históricos de formação dos Estados e à cultura política de cada povo (TARR, 2011). Mesmo aqueles que, em princípio, possuem uma mesma finalidade para adoção do modelo federativo, acabam apresentando diferenças na liberdade deixada ao legislador constituinte estadual, motivadas por essas especificidades históricas e culturais. Na Alemanha, a Lei Fundamental de Bonn não é das mais minudentes sobre organização subnacional, como o é a Áustria, embora, em ambos, tenha-se adotado um federalismo de natureza executiva, em que é dado à União

\footnotetext{
${ }^{4}$ O Distrito Federal detém essa autonomia: "A Lei Orgânica [do Distrito Federal] equivale, em força, autoridade e eficácia jurídicas, a um verdadeiro estatuto constitucional, essencialmente equiparável às Constituições promulgadas pelos Estados-membros": ADIMC n. 980-DF. Rel. Min. Celso de Mello., j. 03/02/1994. A situação dos municípios desperta polêmica. Há quem a negue, por ser o município um elemento político-territorial dos estados-membros. (ARAÚJO; NUNES JÚNIOR, 2011, p. 333). Em sentido oposto, pelo seu reconhecimento no texto da Constituição federal (art. 29, e art. 11, §único, ADCT). (FERRARI, 1994, p. 39; MEIRELLES, 2001, p. 84). Veja-se, por exemplo, RE 590829/MG, j. 5/mar./2015.

5 Pode parecer um contrassenso que a Constituição federal obrigue a adoção de uma Constituição subnacional. No caso brasileiro, o Art. 11 do ADCT não deixa dúvidas. Nos demais, o trabalho ateve-se à dicção constitucional. Os textos consultados empregavam o verbo "debem", quando em espanhol, ou "shall", em inglês. Note-se, porém, que outros autores falam apenas em "permissão": MARSHFIELD, 2011, p. 1161.
} 
elaborar a maioria das políticas públicas, atribuindo-se aos Länder a tarefa de executá-las (GUNLICK, 1998; TARR, 2011, p. 1138).

\section{CONSTITUIÇÕES SUBNACIONAIS E DIREITOS FUNDAMENTAIS}

Os defensores do constitucionalismo subnacional costumam lembrar as contribuições que os textos constitucionais subnacionais têm dado ao reconhecimento de velhos e novos direitos fundamentais para demonstrar-Ihes a importância. A situação, todavia, é bem heterogênea entre os Estados federais ${ }^{6}$. Pode haver uma "declaração de direitos" subnacional, mesmo diante da sua ausência em âmbito federal. É o que sucede na Austrália. A inexistência de um "bill of rights" nacional não impediu do Território da Capital Federal e o Estado de Vitória aprovassem a sua própria declaração em 2004 e 2007, respectivamente (DINAN, 2009, p. 4-5).

Em muitos casos, o texto constitucional das unidades subnacionais apenas duplica as disposições presentes no texto federal. Às vezes, por uma remissão geral, como no caso da Constituição do Estado mexicano da Califórnia de Baixo que prevê que os direitos de seus habitantes "são aqueles garantidos pela Constituição Geral da República" (at. 8). A liberdade de religião assegurada pelas Constituições de Buenos Aires (art. 7(8)) e de Jujuy está presente também na Constituição argentina (art. 14). A proteção constitucional da dignidade humana, liberdade pessoal e de ação na Bavária (arts. 100-102) é repetição da Lei Fundamental de Bonn (arts. 1(1), 2(1) e 2(2)). As Constituições dos cantões suíços de Genebra e Lucerna garantem direitos de igualdade, propriedade, religião e liberdade de expressão, assegurados no texto federal (GARDNER, 2007, p. 14). Essa duplicação pode ser entendida como um expediente supérfluo ou, em defesa do subconstitucionalismo ${ }^{7}$, como um compromisso adicional das unidades subnacionais com os valores e direitos fundamentais de seus cidadãos. É como se, nesse último caso, estivesse a dizer que a tarefa de realizá-los e promovê-los é também um dever subnacional (GARDNER, 2007, p. 15-16).

Às vezes, as disposições de direitos das Constituições subnacionais detalham as previsões existentes no texto federal ou incluem direitos nesse não previstos. A Constituição provincial argentina de Jujuy, por exemplo, reconhece especificamente uma série de direitos,

\footnotetext{
${ }^{6}$ O Tribunal Constitucional espanhol reconheceu que somente no federalismo se pode falar em direitos fundamentais em âmbito subnacional. O "bill of rights" do estatuto da Catalunha não passava de um conjunto de proposições diretivas, a requererem legislação ordinária para serem aplicáveis: ESPANHA, 2007 e 2010. Veja-se ANDREU, 2010; DELLEDONNE, 2011; GAMPER, 2014.

${ }^{7}$ Expressão, por vezes, empregada na literatura: GINSBURG; POSNER, 2010; LORENZ; REUTTER, 2012.
} 
incluindo direitos à dignidade, vida, integridade pessoal, saúde e à igualdade que não se expressam (ou não, da mesma forma) no texto nacional (arts. 18-42). Por lá, mudanças no texto constitucional de algumas províncias inovaram o rol de direitos fundamentais, presentes na Constituição federal, sendo posteriormente, por esta, incorporadas pela Reforma de 1994 (CARNOTA, 2016, p. 73). No México, também houve introdução de direitos não previstos na declaração federal, bem como a instituição de ações destinadas à proteção jusfundamental, inclusive por meio do controle de constitucionalidade no âmbito do estado (GARZA, 2014, p. 77 ss; CARNOTA, 2016, p. 78 ss) ${ }^{8}$.

Na Alemanha, a Lei Fundamental contém uma cláusula geral contra a discriminação baseada, entre outras coisas, na religião, na pátria ou no local de origem (WEISS, 2004, p. 78) ${ }^{9}$. No entanto, cinco dos Länder adotaram garantias constitucionais mais rigorosas para minorias, proporcionando-Ihes maiores oportunidades educacionais, culturais, vocacionais e políticas (WEISS, 2004, p. 80)..$^{10}$ A Constituição da Baviera protege expressamente os direitos da dignidade humana, da liberdade pessoal, da propriedade privada, da consciência, de fala e da imprensa em modo mais expresso e enfático que sua congênere federal. (arts. 98-118). A Constituição da Renânia do Norte-Vestefália fornece proteção expressa aos direitos de

\footnotetext{
${ }^{8} \mathrm{O}$ estado de Veracruz iniciou a onda de redescoberta do constitucionalismo estadual no México com a reforma constitucional realizada em 2000. Introduziu-se um capítulo de direitos humanos não previstos na Constituição federal, além de uma cláusula que incorpora como direito fundamental do estado os que forem estabelecidos em tratados internacionais assinados pelo México. A reforma também criou mecanismos processuais para a proteção da Constituição do estado, designadamente: a) uma espécie de "amparo estadual", para proteção dos direitos fundamentais; b) uma ação de controvérsia constitucional, para resolver disputas de competências entre os poderes públicos estaduais, entre esses e os governos municipais ou, ainda, entre os governos municipais); c) uma ação direta de inconstitucionalidade em nível estadual; e d) uma ação contra omissões legislativas (GARZA, 2014, p. 77-78). A Suprema Corte reconheceu a constitucionalidade dessa reforma (Controvérsia Constitucional n. 16/2000). O "amparo estadual" perdeu força, no entanto, com a admissibilidade de revisão das decisões judiciais dos estados pelo Judiciário federal. Entretanto, a reforma da Constituição federal de 2011 e o reconhecimento, pela Suprema Corte, de que todos os juízes poderia deixar de aplicar leis contrárias aos direitos assegurados na Constituição e nos tratados ratificados pelo México, abriram oportunidade para descentralizar o sistema de controle de constitucionalidade do país: GARZA, 2014, p. 78.

${ }^{9} \mathrm{O}$ constitucionalismo subnacional na Alemanha costuma ser dividido em três fases. A primeira se situa entre 1945 e 1949. É dominada pela aprovação de Constituições analíticas, cujo conteúdo é inspirado pela cultura política dominante na região (sobretudo, católica, por exemplo, na Bavária; e socialdemocrata em Hesse e na Cidade de Bremen). A segunda se inicia com a aprovação da Lei Fundamental de Bonn. As Constituições dos Länder ficaram, à semelhança da federal, muito sucintas. Em alguns casos, sequer declaração de direitos continham. Após a reunificação, dá-se início a terceira fase. Os Länder advindos da antiga Alemanha Oriental aprovaram novas Constituições, enquanto os demais Länder fizeram emendas ao texto em vigor. O resultado foi basicamente o mesmo: um detalhamento maior da Constituição e do "bill of rights" com a incorporação de novos direitos como a privacidade, a proteção ambiental e os direitos sociais. HERDEGEN, 2008, p. 271 ss; DELLEDONNE; MARTINICO, 2011, p. 4-5; 6. 10 Proposta de emenda à Lei Fundamental de igual conteúdo foi rejeitada. WEISS, 2004, p. 77-78.
} 
associação religiosa e ao direito ao trabalho (art. 19). (GARDNER, 2007, p. 14) ${ }^{11}$. Nos Estados Unidos, diversas Constituições estabeleceram mecanismos contra as discriminações com base na raça, gênero e deficiência psicofísica; previram ações afirmativas, o direito à intimidade e vida privada (privacy), os direitos sexuais e reprodutivos da mulher; bem como as garantias processuais e dos encarcerados. Nem sempre, todavia, no sentido de maior proteção (MAY, 1988; SCHEIBER, 1996).

Com ou sem previsão constitucional expressa, em nível federal, muitas Constituições subnacionais reconheceram direitos sociais, econômicos e culturais na Alemanha, na Áustria e na Suíça, por exemplo (GUNLICKS, 1998; BUßJÄGER, 2012; LORENZ; REUTTER, 2012; KARLHOFER, 2015). Quebec, no Canadá, deve ser lembrada por sua peculiaridade. Ao contrário da Carta Canadense de Direitos, a Carta de Quebec protege os direitos sociais e econômicos, como os direitos à habitação, à educação, à informação e à assistência social. Mesmo no seu tratamento dos direitos de "primeira geração", diverge da Carta Canadense (que, claro, a precedeu), incluindo disposições distintivas, relativas aos direitos à dignidade e à reputação, à privacidade, à propriedade e aos segredos profissionais. O problema aqui reside na falta de supremacia da Carta e de sua relativa ineficácia (TARR, 2008, p. 180).

O silêncio federal e a profusão subnacional nessa matéria também são traços marcantes nos Estados Unidos. Por lá, os direitos econômicos, sociais e culturais, desconsiderados como fundamentais pela Suprema Corte do País ${ }^{12}$, foram reconhecidos pelos textos estaduais (HERSHKOFF, 1999). O direito à educação pública está presente em $90 \%$ delas; a proteção aos portadores de necessidades especiais, em 58\%; direitos de bem-estar social dos necessitados, notadamente de proteção, inclusive por meio de assistência econômica e de serviços sociais, em $42 \%$. Dentre os direitos trabalhistas, mencionam-se os direitos sindicais e à greve em $32 \%$, 0 direito às condições seguras de trabalho em 26\%; à jornada de trabalho limitada, em 24\%; à proibição do trabalho infantil, em $20 \%$ e, ao salário mínimo, em $10 \%$. O direito ao meio ambiente saudável também é afirmado em $28 \%$ dos textos constitucionais. Apenas Nova

\footnotetext{
${ }^{11} \mathrm{O}$ problema reside na inexistência de um mecanismo processual adequado para proteção dos direitos perante as cortes constitucionais estaduais, à exceção da Bavária, onde há a "Popularklage" (ação popular). DELLEDONNE; MARTINICO, 2011, p. 5.

12 O direito à educação foi afastado como direito fundamental em San Antonio Independent School District v Rodriguez, 411 US 1, 35 (1973). Sequer deveres positivos de proteção de direitos negativos são reconhecidos: DeShaney $v$ Winnebago County Department of Social Services, 489 U.S. 189, 195-196 (1989).
} 
Hampshire e Vermont não tratam da matéria, enquanto o Arizona, Idaho, Nova lorque, Oklahoma, Montana, Utah e Wyoming mais o fazem (VERSTEEG; ZACKIN, 2014, p. 745-746) ${ }^{13}$.

A ampliação dos direitos políticos com a adoção de mecanismos de controle social de gastos públicos, associados a instrumentos da democracia direta, está presente em diversos textos subnacionais na Alemanha e na Áustria (GUNLICKS, 1998; BUßJÄGER, 2012; LORENZ; REUTTER, 2012; KARLHOFER, 2015). Nos Estados Unidos, trinta e nove estados preveem a figura do referendum; vinte e dois, da iniciativa popular e treze, do recall, concentrando-se, principalmente, nos estados do Oeste (FAVOREU, 2006, p.402). Em alguns estados, como a Califórnia, prevê-se a possibilidade de uma "emenda constitucional popular" sem intervenção da legislatura (SCHEIBER, 1996, p.796-797) ${ }^{14}$. Na Suíça, a vida política dos cantões é marcada pelo referendo, plebiscito e iniciativa popular (EDER; VATTER; FREITAG, 2009).

Esse maior ou menor elenco de direitos depende, pelo menos, em parte, do grau de preordenação e do sistema de repartição de competências previsto na Constituição federal. Direitos que digam respeito a matérias afetas à competência privativa da União não podem ser tratados subnacionalmente, embora haja quem admita a repetição exata no texto subnacional como instrumento de reforço ao compromisso com a efetividade dos direitos (SAMPAIO, 2013). Se, por outro lado, disserem respeito a assuntos situados no âmbito da competência concorrente ou privativa da unidade subnacional, há um espaço maior de criatividade do constituinte (WATTS, 1999; GINSBURG; POSNER, 2010). No primeiro caso, porém, deve seguir o critério de divisão de tarefas entre centro e periferia, se existir. Na África do Sul, o Tribunal Constitucional já afirmou que a declaração de direitos das províncias não deve ser "incompatível" com a Constituição federal (ÁFRICA DO SUL, 1996, p. 31), nem pode tratar de questões que estejam fora de suas competências legislativas ou executivas (ÁFRICA DO SUL, 1996, p. 33-34). A enunciação de direitos nas Constituições provinciais, portanto, não pode ser um mero espelho da declaração de direitos constante da Constituição federal nem pode dispor sobre matérias tratadas, por preempção, pela legislação nacional (MARSHFIELD, 2008, p. 597).

\footnotetext{
13 Há uma crítica recorrente de que as Constituições estaduais incorporaram temas, como energia, utilidade pública, estradas, esportes e jogos, questões trabalhistas, educacionais e ambientais, que deveriam ser tratados pela legislação ordinária, comprometendo a legitimidade e a efetividade das Constituições: FRIEDMAN, 1988, p. 36; THOMPSON JR, 1996; SCHEIBER, 1996, p. 809-810.

${ }^{14} \mathrm{Na}$ Áustria, previsão análoga, na Constituição de Vorarlberg, foi reputada inconstitucional (VfSlg 16.241/2001). De acordo com essa previsão, um projeto de lei, de iniciativa popular, seria obrigatoriamente aprovado nas seguintes circunstâncias: a) não implementação da iniciativa pelo Parlamento; b) aprovação da lei em referendo, que seria obrigatório, no caso. Embora a Constituição federal deixasse para os Länder a disciplina de seus mecanismos de democracia direta (art. 117(8)), o constituinte estadual teria violado o princípio da democracia representativa (GAMPER, 2014, p. 30).
} 
Como aquela declaração é muito detalhada e a legislação nacional é farta, sobra pouco espaço para inovação provincial (ÁFRICA DO SUL, 1996, p. 33-34). Talvez por isso a Constituição do Cabo Ocidental, a única em vigor entre as províncias sul-africanas, não tenha uma declaração de direitos, limitando-se a enumerar os "princípios diretivos da política provincial" (MARSHFIELD, 2008, p. 594-595).

As Constituições subnacionais podem ser ainda um importante instrumento de proteção dos direitos das minorias. Embora a Constituição dos Estados Unidos seja silente, o texto constitucional do Novo México criou a obrigação para as escolas do ensino bilíngue, em inglês ou espanhol (art. XII (8)). A Constituição do Havaí prevê a proteção dos nativos havaianos (art. XII) e a de Montana reconhece o patrimônio cultural distinto e único dos índios americanos, associado à tarefa estatal de promover a educação, de modo a preservar a sua integridade cultural (art. I(2)(2)).(TARR; PORTER, 1982; TARR, 2001). Os direitos dos povos nativos também são resguardados nos estados mexicanos (GONZÁLEZ, 2005, p. 214). As Constituições de diversos estados etíopes, na mesma linha, reconhecem a língua própria como oficial (TARR, 2008, p. 192) ${ }^{15}$ e muitos Länder alemães salvaguardam os direitos linguísticos das minorias (WEISS, 2004, p. 80-81).

Como se pode ver, o constitucionalismo subnacional nas federações tem relevância na proteção dos direitos, seja repetindo, seja inovando a Constituição federal. Os Estados Unidos merecem uma atenção a esse respeito, até por ter servido de inspiração para o desenvolvimento do "constitucionalismo subnacional" em outros lugares (VERSTEEG; ZACKIN, 2014). É, por lá, arraigada a ideia de que os indivíduos gozam de dupla afirmação e proteção de seus direitos: de âmbito federal e em sede das Constituições estaduais. O juiz Brennan é sempre lembrado como aquele que "redescobriu" a proteção mais ampla dos direitos individuais pelas Constituições estaduais, dando origem ao "novo federalismo judicial", ao afirmar que os Estados funcionam como laboratórios de experiências democráticas, cujo sucesso pode ser reproduzido pelos outros Estados e pela União, assim como evitado, por eles, o fracasso (BRENNAN JR, 1977, p. 503)16. A história do "subconstitucionalismo" daquele país revela o quanto as Constituições estaduais se anteciparam à Constituição federal na declaração de direitos: o reconhecimento da igual proteção da lei (WILLIAMS, 1985), do "devido processo

\footnotetext{
${ }^{15}$ Embora sejam menos deferentes em relação aos demais direitos das minorias e aos direitos coletivos, comparativamente à proteção dos direitos individuais: REGASSA, 2009, p. 54-55, 58.

16 "[l]t is one of the happy incidents of the federal system that a single courageous state may, if its citizens choose, serve as a laboratory, without risk to the rest of the country." ESTADOS UNIDOS, 1932 (voto dissidente). Ver SAVAGE, 1985.
} 
substantivo" (ZACKIN, 2013, p. 91 ss, 134), dos direitos políticos dos afro-americanos, das mulheres, da redução da idade de voto para os dezoito anos e da extinção de impostos para votar que impunham, na prática, restrição censitária à cidadania, sem contar a previsão de mecanismos de participação popular direta (McDONAUGH; PRICE, 1985, p. 415 ss; KEYSSAR, 2000, p. 130 ss; 332).

Em muitos casos, são os tribunais estaduais que leem no conjunto normativo dos respectivos textos constitucionais a existência de direitos negados ou negligenciados no âmbito federal. Deu-se assim com o reconhecimento, pela Suprema Corte da Califórnia, de que a pena de morte, por ser cruel, é incompatível com a Constituição (ESTADOS UNIDOS, 1972) ${ }^{17}$. A afirmação de que as Constituições estaduais abrigavam direitos positivos, como a educação, também foi produto dessa mesmo processo (PARIS, 2009, p. 9 ss; LEVINSON, 2011, p. 812 ${ }^{18}$ ). Na mesma linha, antes de a Suprema Corte reconhecer o status jurídico das uniões homoafetivas, decisões das Supremas Cortes de Massachusetts, da Califórnia, de Connecticut e lowa já o haviam feito, baseadas numa interpretação sistemática dos respectivos textos constitucionais ${ }^{19}$. Assim também sucedendo com outros direitos sexuais e reprodutivos ${ }^{20}$.

A resposta a essas interpretações judiciais da Constituição pode ser a incorporação do novo direito ao texto constitucional, mas não é raro que haja emendas à Constituição subnacional que procuram desqualificá-las e proibir que prevaleçam. Deu-se, assim, por exemplo, em Massachusetts no ano de 1982, diante da decisão da Suprema Corte estadual de que a pena de morte violaria a Constituição do Estado e, na Luisiana, diante da afirmação judicial de direitos sexuais e reprodutivos (VERSTEEG; ZACKIN, 2014, p. 718). Essa oposição da área política ao ativismo judicial reforça a ideia de que as Constituições estaduais mudam de

\footnotetext{
${ }^{17}$ A decisão foi superada pela Emenda 17 (Proposition 17). SHATZ; RIVKIND, 1997.

18 Interessante a análise de Levinson sobre a vinculação dos juízes estaduais aos eleitores, não apenas nos Estados onde há são, de alguma forma, eleitos, cerca de $90 \%$ deles, mas nos outros, associada à existência de mandato e não de vitaliciedade, o que poderia explicar o ativismo (p. 812-813).

19 Citem-se, dentre outras: Goodridge v. Dep't of Pub. Health, 798 N.E.2d 941 (Mass. 2003); In re Marriage Cases, 183 P.3d 384 (Cal. 2008); Kerrigan v. Comm'r of Pub. Health, 957 A.2d 407 (Conn. 2008); Varnum v. Brien, 763 N.W.2d 862 (lowa 2009): BULFER, 2010.

${ }^{20}$ O pioneiro reconhecimento das uniões homoafetivas pelos Estados da Califórnia, Connecticut, lowa e Massachusetts levou alguns Estados como o Alabama, Alaska, Arizona, Arkansas, Colorado, Flórida, Geórgia, Havaí, Idaho, Kansas, Kentucky, Louisiana, Michigan, Mississippi, Missouri, Montana, Nebraska, Dakota do Norte e do Sul, Ohio, Oklahoma, Oregon, Carolina do Sul, Tennessee, Texas, Utah, Virginia e Wisconsin, a incluírem em seu texto constitucional que o instituto do casamento envolvia sempre um homem e uma mulher. No caso do aborto, as reações também são nos dois sentidos. Em diversos Estados, tentou-se uma restrição que, na prática, tentava inviabilizar a prática; noutros, porém, instituiu ou manteve o financiamento público para realização de abortamento, depois que a Suprema Corte não o considerou uma questão constitucional federal. TARR, 2011, p. 1141, n. 26, 1147-1148.
} 
acordo com os ventos da maioria. (POPE, 1993, p. 985; GINSBURG; POSNER, 2010, p. 1606 ss) e podem ser um perigoso instrumento de revanche das forças reacionárias estaduais, pondo em risco conquistas de âmbito federal (TRIBE, 1977) ${ }^{21}$. Não se pode deixar de notar, entretanto, que esses "embates" e "convergências", tanto em nível estadual, entre a jurisprudência e os legislador de reforma das Constituições estaduais, quanto entre estados e federação, alargam os espaços de diálogo interinstitucional tão caros à democracia, aos direitos e ao próprio federalismo (FEELEY; RUBIN, 2008; SCHAPIRO, 2009).

Enfim, se há, nos Estados Unidos, um dinâmico sistema dualista de proteção jusfundamental, as peculiaridades sociológicas, políticas ou territoriais de outras federações podem dispensar uma declaração de direitos subnacionais sem que isso comprometa os direitos das pessoas. A Bélgica é um exemplo. A pequena extensão territorial, aliada a uma proteção de direitos de âmbito federal e supranacional, ancorada na Corte Europeia de Direitos Humanos, não exigiria necessariamente um acréscimo subnacional (POPELIER, 2012, p. 50). Mesmo assim parece que a duplicação do sistema de proteção jusfundamental, ainda que levante dúvidas sobre a efetividade (e, por consequência, necessidade) dos mecanismos subnacionais, tem um forte apelo simbólico e político de compromisso com os direitos e com a escolhas fundamentais de uma sociedade (PAS, 2004, p. 169).

\section{OS DIREITOS FUNDAMENTAIS NAS CONSTITUIÇÕES ESTADUAIS BRASILEIRAS}

O tratamento dispensado pelo constituinte estadual no Brasil aos direitos fundamentais tem nuances que merecem análise. Em nove estados, a Constituição não os prevê em título, capítulo ou artigo próprios nem sequer em remissão à Constituição federal: Acre, Alagoas, Ceará, Goiás, Mato Grosso do Sul22, Pernambuco, Rondônia, São Paulo e Tocantins. A remissão está presente nos demais. A inexistência da remissão, no entanto, não quer dizer que haja silêncio constitucional absoluto sobre o tema, pois os direitos são reconhecidos como princípio

\footnotetext{
${ }^{21}$ Inclusive e, paradoxalmente, por meio de consulta popular ou "emenda constitucional popular", a sugerir que nem sempre a democracia direta amplia o sistema de direitos: SCHEIBER, 1996, p. 796-797.

22 A Constituição sul-matogrossense faz menção como fundamentos ao respeito aos princípios fundamentais estabelecidos na Constituição Federal, à dignidade da pessoa humana e aos valores sociais do trabalho e da livre iniciativa (art. 10, II a IV) e, como objetivos fundamentais, construir uma sociedade livre, justa e solidária, sem quaisquer formas de discriminação; e garantir o desenvolvimento estadual; III reduzir as desigualdades sociais. (art. 3ㅇ, I e III).
} 
ou tarefa do estado. ${ }^{23}$ Tratamento, aliás, que não é muito distinto de alguns que a fazem como Paraná $^{24}$, Rio Grande do Sul ${ }^{25}$ e Roraima ${ }^{26}$, além do Distrito Federal (art. 3ำ, I). As consequências práticas, ao fim, são as mesmas.

A referência à Constituição federal pode, portanto, cingir-se à definição dos direitos consagrados como elemento principiológico, objetivo ou de fundamento do estado (Paraná, Rio Grande do Sul e Roraima) ou do Distrito Federal. Em quatorze, todavia, dedica-se um capítulo ou título ao assunto: Amazonas, Bahia, Espírito Santo, Maranhão, Mato Grosso, Minas Gerais, Pará, Paraíba, Piauí, Rio Grande do Norte, Rio de Janeiro, Roraima, Santa Catarina e Sergipe. A técnica constituinte de capítulo ou título próprios, por sua vez, pode não importar mais que a mera remissão à Constituição federal.

No Maranhão, por exemplo, o Título II sobre "Direitos e Garantias Fundamentais", contém dois artigos, um, realmente, relacionado a direitos ("é assegurada, no seu território e nos limites de sua competência, a inviolabilidade dos direitos e garantias fundamentais, nos termos da Constituição Federal" - art. 4ํ). O outro trata de proibições federativas semelhantes às que se encontram no Art. 19 da Constituição federal ${ }^{27}$. Assim também em Roraima, o Título II

\footnotetext{
${ }^{23}$ Assim, em Alagoas (Art. 2o É finalidade do Estado de Alagoas, guardadas as diretrizes estabelecidas na Constituição Federal, promover o bem-estar social, calcado nos princípios de liberdade democrática, igualdade jurídica, solidariedade e justiça, cumprindo-lhe, especificamente: I - assegurar a dignidade da pessoa humana, mediante a preservação dos direitos invioláveis a ela inerentes, de modo a proporcionar idênticas oportunidades a todos os cidadãos, sem distinção de sexo, orientação sexual, origem, raça, cor, credo ou convicção política e filosófica e qualquer outra particularidade ou condição discriminatória, objetivando a consecução do bem comum); São Paulo (artigo 2o: A lei estabelecerá procedimentos judiciários abreviados e de custos reduzidos para as ações cujo objeto principal seja a salvaguarda dos direitos e liberdades fundamentais); e em Tocantins (art.. 2o, I - garantir os direitos dos indivíduos e os interesses da coletividade e, ainda, a defesa dos direitos humanos e da igualdade, combatendo qualquer forma de discriminação); e no Mato Grosso do Sul (art. 10 O Estado de Mato Grosso do Sul tem como fundamentos: I - a preservação da sua autonomia como unidade federativa; || - o respeito aos princípios fundamentais estabelecidos na Constituição Federal; III - a dignidade da pessoa humana).

${ }^{24} \mathrm{Art.} 1^{\circ}$. O Estado do Paraná, integrado de forma indissolúvel à República Federativa do Brasil, proclama e assegura o Estado democrático, a cidadania, a dignidade da pessoa humana, os valores sociais, do trabalho e da livre iniciativa, o pluralismo político e tem por princípios e objetivos: I - o respeito à unidade da Federação, a esta Constituição, à Constituição Federal e à inviolabilidade dos direitos e garantias fundamentais por ela estabelecidos.

${ }^{25}$ Art. 10 - O Estado do Rio Grande do Sul, integrante com seus Municípios, de forma indissolúvel, da República Federativa do Brasil, proclama e adota, nos limites de sua autonomia e competência, os princípios fundamentais e os direitos individuais, coletivos, sociais e políticos universalmente consagrados e reconhecidos pela Constituição Federal a todas as pessoas no âmbito de seu território.

${ }^{26}$ A remissão, em Roraima, é apenas à igualdade: "Art. 40 Todos são iguais perante a Lei, nos termos da Constituição Federal".

${ }^{27}$ Art. 5o - É vedado ao Estado e ao Município: I - estabelecer cultos religiosos ou igrejas, subvencionálos, embaraçar-lhes o funcionamento ou manter, com eles ou seus representantes, relações de dependência ou aliança, ressalvada, na forma da lei, a colaboração de interesse público; II - recusar a fé aos documentos públicos; III - criar distinções entre brasileiros ou preferências entre si.
} 
é dividido em dois Capítulos, cada um com um artigo. No primeiro, dispõe-se que todos são iguais perante a lei nos termos da Constituição federal (art. 4ํ); no outro, proclama-se que são "direitos sociais: a educação, a saúde, o trabalho, o lazer, a segurança, a previdência social, a proteção à maternidade e à infância, a assistência aos desamparados, na forma do disposto na Constituição Federal" (art. 5ํ).

Alguns textos, que fazem remissão à Constituição federal, dedicam-se a resguardar os direitos dos presos (Amazonas, art. 3ㅇ, §§ 11 e 12; Bahia, art. 4으, X a XIV; Minas Gerais, art. 4ㅇ, $\S$

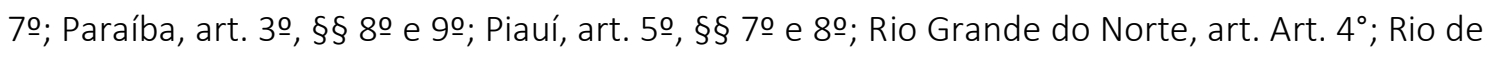
Janeiro, art. 2728; Santa Catarina, art. 4ㅇ, $11^{29}$; Sergipe, art. 3ㅇ, $\S \S 70$ a 10ㅇ) e prevenir e reprimir abuso da policia (Sergipe, art. 3ํ, Vl; Mato Grosso, art. 10, XV); a reforçar a vedação de discriminação das pessoas por origem, raça, cor, gênero, orientação sexual, crença religiosa ou convicção política ou filosófica (Espírito Santo, art. 3ำ § único; Paraíba, art. 3ㅇ, § 3ㅇ; Mato Grosso, art. 10, III; Rio de Janeiro, art. 9o, § 1ㅇ; Santa Catarina, art. 4ㅇ, IV; Sergipe, art. 3으, II) ${ }^{30}$, por vínculo ou relação político-partidária (Rio Grande do Norte, art. 6ํㅜㄹ) ou por litigar contra o estado (Amazonas, art. 3ㅇ, § 8ㅇ; Bahia, art. 4으, IV; Mato Grosso, art. 10, V; Minas Gerais, art. 4으, § 3ㅇ; Pará, art. 5으, § 3ㅇ; Piauí, art. 5ㅇ, § 3ㅇ; Rio de Janeiro, art. 18; Sergipe, art. 3ㅇ, XXI);

Está também previsto o respeito do direito à vida, à liberdade, à igualdade, à segurança e à propriedade (Pará, art. 4ㅇ); à intimidade (Rio de Janeiro, art. 22), à liberdade de consciência e crença (Rio de Janeiro, art. 22, § 1으); a garantia do exercício do direito de propriedade (Mato Grosso, art. 10, VIII), de reunião (Bahia, art. 4으, III; Rio de Janeiro, art. 23; Sergipe, art. 3ㅇ, III ${ }^{32}$ ) e de outras liberdades constitucionais e a defesa da ordem pública, da segurança pessoal e dos patrimônios público e privado (Amazonas, art. 3ำ § 60; ${ }^{33}$ Mato Grosso, art. 10, XIV; Minas

28 Inclui a garantia de liberdade, salvante flagrante delito ou por ordem escrita e fundamentada de autoridade judiciária competente, salvo nos casos de transgressão militar ou crime propriamente militar, definidos em lei (art. 29).

29 "O sistema penitenciário estadual garantirá a dignidade e integridade física e moral dos presidiários, facultando-Ihes assistência espiritual e jurídica, aprendizado profissionalizante, trabalho produtivo e remunerado, bem como acesso aos dados relativos a execução das respectivas penas."

${ }^{30}$ A garantia também aparece na Lei Orgânica do Distrito Federal (art. 2o,parágrafo único).

${ }^{31}$ Art. $6^{\circ}$. A lei coíbe a discriminação política e o favorecimento de partidos ou grupos políticos pelo Estado, autoridades ou servidores estaduais, assegurando ao prejudicado, pessoa física ou jurídica, os meios necessários e adequados à recomposição do tratamento igual para todos.

32 Como dever de proteção da polícia: as autoridades policiais assegurarão a livre reunião e as manifestações pacíficas, individuais e coletivas.

${ }^{33}$ A redação do dispositivo todavia é digna de atenção "A força policial só poderá intervir para garantir o exercício do direito de reunião e demais liberdades constitucionais, bem como a defesa da ordem pública e do patrimônio público e privado e a segurança pessoal, cabendo responsabilidade aos agentes pelos 
Gerais, art. 4ㅇ, § 60; Paraíba, art. 3ำ, § 6ㅇ; Piauí, art. 5ํ, § 6ㅇ); bem como a assistência religiosa e espiritual a doentes, reclusos ou detentos (Bahia, art. 4으, XVII; Pará, art. 5ㅇ, § 5²).

Nalgumas Constituições, há a garantia expressa do devido processo legal (Rio de Janeiro, art. 25), do direito a um advogado e gratuito, se necessitado (Bahia, art. 40, VIII; Rio de Janeiro, art. 30; Sergipe, art. 3이 XX), à razoável duração do processo judicial ou administrativo (Bahia, art. 4ㅇ, XVIII; Espírito Santo, art. 6o-A; Piauí, art. 5ำ § 9o), indenização integral aos condenados por erro judiciário e àquele que ficar preso além do tempo fixado na sentença (Sergipe, art. 3ำ XXIII). No Rio de Janeiro, há uma proclamação reiterada de respeito à dignidade humana como se lê no Art. 8o: "Todos têm o direito de viver com dignidade".

Na raramente, imputam a responsabilidade administrativa da autoridade que, por omissão, tornar inviável o exercício dos direitos (Amazonas, art. 3ㅇ, § 1ㅇ; Bahia, art. 4ㅇ, II; Espírito Santo, art. 60; Mato Grosso, art. 10, II; Minas Gerais, art. 4으, § 10³4; Pará, art. 5ㅇ, § 20; Paraíba, art. 3ㅇ, § 1ㅇ; Piauí, art. 5ㅇ, § 1ㅇ; Rio de Janeiro, art. 10; Santa Catarina, art. 4ㅇ, I) ou, mesmo por ação, atentar contra os direitos (Mato Grosso, art. 4ㅇ, IV; Minas Gerais, art. 4ㅇ, § 8ㅇ; Pará, art. 5ㅇ, § $1^{\circ}$.).

No campo dos direitos políticos a maioria dos textos estaduais repete sucintamente a Constituição federal com sua dominância do processo democrático representativo e formas excepcionais de intervenção popular por meio do plebiscito, referendum e iniciativa popular. Em alguns deles, porém, há um reforço à democracia participativa e direta. Merecem lembrança o texto amazonense ${ }^{35}$, baiano, ${ }^{36}$ do Espírito Santo, ${ }^{37}$ do Pará $^{38}$ e, em tom mais

excessos que cometerem". É a mesma do Piauí (art. 5ㅇ, § 6ㅇ). O parágrafo 10 do Amazonas repete a Constituição federal: "Todos podem reunir-se pacificamente, sem armas, em locais abertos ao público, independentemente de autorização, desde que não frustrem outra reunião anteriormente convocada para o mesmo local, sendo apenas exigido prévio aviso à autoridade competente".

34 "Incide na penalidade de destituição de mandato administrativo ou de cargo ou função de direção, em órgão da administração direta ou entidade da administração indireta, o agente público que deixar injustificadamente de sanar, dentro de noventa dias da data do requerimento do interessado, omissão que inviabilize o exercício de direito constitucional".

${ }^{35}$ Art. 70. A sociedade integrará, através de representantes democraticamente escolhidos, todos os órgãos de deliberação coletiva, estaduais ou municipais, que tenham atribuições consultivas, deliberativas ou de controle social nas áreas de educação, cultura, saúde, desenvolvimento socioeconômico, meio ambiente, segurança pública, distribuição de justiça, assistência e previdência social e defesa do consumidor.

${ }^{36}$ Art. 64 - Será garantida a participação da comunidade, através de suas associações representativas, no planejamento municipal e na iniciativa de projetos de lei de interesse específico do Município, nos termos da Constituição Federal, desta Constituição e da Lei Orgânica municipal. Parágrafo único - A participação referida neste artigo dar-se-á, dentre outras formas, por: I - mecanismos de exercício da soberania popular; e II - mecanismos de participação na administração municipal e de controle dos seus atos.

${ }^{37}$ Art. 4 o Todos têm direito a participar, pelos meios legais, das decisões do Estado e do aperfeiçoamento democrático de suas instituições, exercendo a soberania popular pelo sufrágio universal e pelo voto 
programático, o do Rio de Janeiro ${ }^{39}$. O acesso à informação é uma característica recorrente nas Constituições dos estados, como em Alagoas (art.44, IX), Amazonas (art. 3o, § 5o), Bahia (art. 31, $\S$ único, II), Espírito Santo (art. 23, XII), Mato Grosso (arts. 10, XI; e 16), Minas Gerais (art. 4o, §

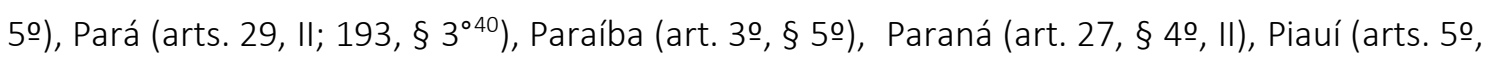
$\S 5$ ㅇ, e 6ㅇ), Rio Grande do Norte (art. 7으), Rio Grande do Sul (art. 23), Rio de Janeiro (arts. 19 e 20), Roraima (art. 26), Santa Catarina (art. 18, II) e Sergipe (art. 3ㅇ, XII e § 5ㅇ).

Os direitos sociais, econômicos e culturais, por sua vez, têm tratamento disperso em todos os textos estaduais e, em alguns, são reconhecidos em capítulo ou artigo próprios, a exemplo do Amazonas, Espírito Santo, Mato Groso, Paraíba, Piauí, Rio Grande do Norte, Rio de Janeiro e Roraima. Na Bahia, Goiás e Maranhão, encontram-se dentro da "ordem econômica e social"; em Minas Gerais, Pará, Paraná, Santa Catarina e Sergipe, integram a "ordem social" e, no Ceará, as "responsabilidades culturais, sociais e econômicas"41. Os direitos trabalhistas raramente têm destaque, seja pelo extenso elenco federal, seja pela competência da União para legislar sobre direito do trabalho (art. 22, I). Amazonas, Espírito Santo, Mato Grosso, Pará e Rio de Janeiro avançam sobre esse tema em alguns dispositivos.

No Amazonas, assegura-se a dignificação do trabalho e a garantia de piso salarial adequado e justo (art. 4ํ, VII); a fiscalização da observância, por parte de todos, das condições de trabalho estabelecidas em lei (art. 4ㅇ, VII); o direito de creche aos filhos de trabalhadores de empresas que desfrutem de benefícios fiscais ou financeiros estaduais ou municipais e possuam

direto e secreto, além do plebiscito, do referendo e da iniciativa popular no processo legislativo. Parágrafo único. O Estado prestigiará e facultará, nos termos da lei, a participação da coletividade na formulação e execução das políticas públicas em seu território, como também no permanente controle popular da legalidade e da moralidade dos atos dos Poderes Públicos. Art. 5o Fica assegurado, na forma da lei, o caráter democrático na formulação e execução das políticas e no controle das ações governamentais através de mecanismos que garantam a participação da sociedade civil.

${ }^{38} \mathrm{Art}$. $7^{\circ}$. Através de plebiscito, o eleitorado se manifestará, especificamente, sobre fato, medida, decisão política, programa ou obra pública, e, pelo referendo, sobre emenda à Constituição, lei, projetos de emenda à Constituição e de lei, no todo ou em parte. $\S 1^{\circ}$. Pode requerer plebiscito ou referendo: I - um por cento do eleitorado estadual; II - o Governador do Estado; III - um quinto, pelo menos, dos membros da Assembleia Legislativa. Dispõe, entretanto, o $\S 2^{\circ}$ : A realização do plebiscito ou referendo depende de autorização da Assembleia Legislativa.

${ }^{39}$ Art. 1 - - O povo é o sujeito da Vida Política e da História do Estado do Rio de Janeiro. (...). Art. 4o - O Estado do Rio de Janeiro é o instrumento e a mediação da soberania do povo fluminense e de sua forma individual de expressão, a cidadania. (...).

${ }^{40} \mathrm{~A}$ qualquer entidade ou pessoa ligada à defesa dos direitos humanos, é garantido o acesso a dados, informações, inquéritos judiciais e extrajudiciais, inclusive militares, sobre violência e constrangimento ao ser humano. (art. 195, § $3^{\circ}$ ).

${ }^{41}$ Numa redação menos adequada, pela sua dubiedade, a Lei Orgânica do Distrito Federal os reconhece no âmbito da assistência social: "A assistência social é dever do Estado e será prestada a quem dela necessitar, independentemente de contribuição a seguridade social, assegurados os direitos sociais estabelecidos no art. 6o da Constituição Federal” ( art. 217). 
número de empregados superior a cem, bem como de qualquer empresa com número de empregados superior a duzentos (art. 8o); e ainda a liberdade sindical e a greve (art. 5ㅇ). Essa dupla de direitos também está presente na Constituição do Rio de Janeiro (arts. 40 e 41). A liberdade sindical ainda é resguardada no Espírito Santo (art. 13) e no Mato Grosso (art. 12). No Pará, assegura-se que ninguém poderá ser penalizado, especialmente com a perda do cargo, função ou emprego, quando se recusar a trabalhar em ambiente que ofereça iminente risco de vida, salvo quando inerente à atividade exercida e desde que seja dada a devida proteção (art. 5o, $\left.\S 4^{\circ}\right)$. Assim também, dispõe-se que nenhuma pessoa poderá ser submetida a condições degradantes de trabalho ou a práticas análogas ao trabalho escravo, seja em ambiente doméstico ou rural, nem a qualquer outro constrangimento que não os provenientes do ordenamento constitucional da União e do estado do Pará. (art. 5ㅇ, § $6^{\circ}$ )

O texto fluminense é um dos mais detalhados no tratamento dispensado aos direitos sociais. Dispõe o parágrafo único do Art. 8o: "É dever do Estado garantir a todos uma qualidade de vida compatível com a dignidade da pessoa humana, assegurando a educação, os serviços de saúde, a alimentação, a habitação, o transporte, o saneamento básico, o suprimento energético, a drenagem, o trabalho remunerado, o lazer e as atividades econômicas, devendo as dotações orçamentárias contemplar preferencialmente tais atividades, segundo planos e programas de governo".

A gratuidade dos serviços públicos estaduais é assegurada em alguns textos constitucionais, normalmente, repetindo-se as hipóteses previstas na Constituição federal. Noutros, vai-se além. No Rio de Janeiro, aplica-se ao transporte coletivo e aos portadores de doença crônica, que exija tratamento continuado e cuja interrupção possa acarretar risco de vida; ou de deficiência com reconhecida dificuldade de locomoção (art 14). Na Bahia, "comprovada a absoluta incapacidade de pagamento, definida em lei, ninguém poderá ser privado dos serviços públicos de água, esgoto e energia elétrica" (art. 4ํ,I). No Espírito Santo e Sergipe, a dicção constitucional de tão ampla pode gerar dubiedade. De acordo com o texto capixaba, "ninguém poderá ser privado dos serviços públicos essenciais" (art. 9o̊). Em Sergipe, lê-se que "ninguém será prejudicado no exercício de direito, nem privado de serviço essencial à saúde, à higiene e à educação, por não dispor de recursos financeiros" (art. 3o, I). A depender do alcance interpretativo, a gratuidade pode estender-se a todos os domínios dos direitos fundamentais.

O direito do consumidor, da criança, do adolescente, do idoso e a proteção ao meio ambiente, de regra, como um direito fundamental, são encontrados em todas as Constituições 
dos estados. Chama a atenção, ainda, o apelo à diversidade social e às minorias. Há dispositivo de proteção às comunidades indígenas em quase todas elas, com exceção do Ceará, Minas Gerais e Piauí. No Rio Grande do Norte, restringe-se às suas manifestações culturais $\left(143, \S 1^{\circ}\right)$. No Distrito Federal, impõe-se que sejam estudadas nas escolas as lutas dos índios nos processos históricos (art. 235, § 3ㅇ). No Amazonas, a expressão é mais adequada à realidade local, falando-se em "povo da floresta" (Cap. XIII). É no Amazonas também que se trata da população ribeirinha e "grupos nativos extrativistas" (Cap. XIII, art. 251). Os quilombolas ganham algum nível de proteção em pelo menos três Constituições (Pará, art. 286 § 2; Paraíba, arts. 252A e B; e Goiás, art. 16, ADCT); e os ciganos, apenas em uma (Paraíba - arts. 252A e B).

Os direitos dos afro-brasileiros aparecem em diversos textos estaduais. No Amapá, preveem-se formas de igualação de oportunidade e de inclusão social, inclusive por meio de ação afirmativa de caráter reparatório ${ }^{42}$. Na Bahia, há um reconhecimento solene de que a "sociedade baiana é cultural e historicamente marcada pela presença da comunidade afro-

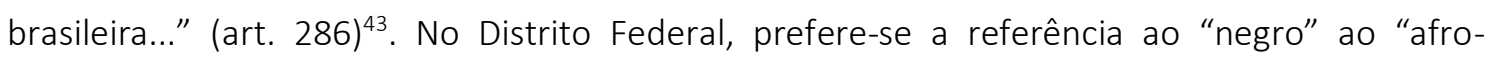
brasileiro", reconhecendo-se-Ihe a proteção contra a violência e discriminação (art. 276) e determinando-se que o currículo escolar e o universitário devam incluir, no conjunto das disciplinas, conteúdo sobre as lutas dos negros, bem como das mulheres, dos índios e de outros na "história da humanidade e da sociedade brasileira". ( art. 235, § 3ํ). Prevê-se, ainda, a criação de um Conselho de Defesa dos Direitos do Negro (art. 24, ADT)

Na maioria dos estados, à cópia do modelo federal, é afirmada a tarefa estatal de promoção da cultura afro-brasileira (Amazonas, art. 205, VI; Espírito Santo, art. 181, III; Goiás, art. 163, § 2o; Mato Grosso, art. 248, III, § 1o; Pará, art. 277 § 1; Paraíba, art. 214; Rio de Janeiro, art. 322 VII; Rio Grande de Norte, art. $143 \S 1^{\circ}$; e Tocantins (art. 138, § 3ㅇ). Noutros, os afro-brasileiros parecem incluídos implicitamente na referência à etnia, por meio da valorização da sua diversidade (Ceará, art. 180,§ 2o; Maranhão, art. 262; Pernambuco, art. 180, § 2oo; Piauí,

\footnotetext{
42 Art. 332-A. Aos afro-brasileiros, assim definidos em lei, além dos direitos e garantias fundamentais consagrados pela Constituição Federal e por esta Constituição, é assegurado igualdade de oportunidade e tratamento em sua participação na vida econômica, social, política e cultural decorrente do desenvolvimento de políticas públicas no âmbito do Estado do Amapá, por meio de: Parágrafo único. Os programas de ação afirmativa constituir-se-ão em imediatas iniciativas reparatórias, destinadas a promover a correção das distorções e desigualdades raciais decorrentes do processo de escravidão e das demais práticas discriminatórias adotadas durante todo o processo de formação social do Brasil e poderão utilizar-se da estipulação de cotas para consecução de seus objetivos.

${ }^{43}$ Dispõe o artigo 50, do ADCT: "O Estado promoverá, no prazo máximo de doze meses a contar da data da promulgação desta Constituição, as ações necessárias à legalização dos terrenos onde se situam os templos das religiões afro-brasileiras, por iniciativa da competente Federação".
} 
art. 229, § 3ำ, V), de sua expressão cultural (Rio Grande do Sul, art. 220, § único ${ }^{44}$ ), preservação de suas tradições e costumes (Santa Catarina, art. 173, único, VII), ou como grupo social formador da sociedade brasileira ou local, a merecer proteção (Acre, arts. 201, § 20; 202; Roraima, art. 159). Não há menção a qualquer das duas formas no Paraná.

A proteção da mulher é recorrente em praticamente todos os textos, no mínimo, por cópia à Constituição federal no tocante ao mercado de trabalho, à maternidade e à igualdade com o homem, notadamente na sociedade conjugal. Algumas Constituições estaduais procuram ir além, com o parcial resguardo a seus direitos sexuais e reprodutivos, especialmente em relação à interrupção da gravidez, desde que admitida legalmente, há essa ressalva sempre. No Rio de Janeiro (art. 35) e em São Paulo (art. 223, X), garante-se, com a mesma literalidade, "o direito à autorregulação da fertilidade como livre decisão da mulher, do homem ou do casal, tanto para procriar como para não o fazer". No Amapá (art. 265), na Bahia (art. 282, III), em Goiás (art. 153, XIV), em Minas Gerais (art. 190, X) e no Paraná (art. 176), atribui-se a tarefa estadual de assistência à interrupção da gravidez, nos casos admitidos em lei, ou, no Pará (art. 299, IV), de acesso gratuito aos métodos contraceptivos naturais ou artificiais. No Amazonas, assegura-se "à mulher livre opção pela maternidade, compreendendo-se como tal a assistência ao pré-natal, parto e pós-parto, a garantia do direito de evitar e, nos casos previstos em lei, interromper a gravidez sem prejuízo para a sua saúde" (art. 186). No Espírito Santo, por outro lado, é considerado "inaceitável, por atentar contra a vida humana, o aborto diretamente provocado" (art. 199, § único).

Há também uma preocupação com a violência contra a mulher em casa e no trabalho (Amapá, art. 329, III; Mato Grosso do Sul, art. 253) ou no âmbito doméstico e familiar (Acre, art. $209 \S 2$ 2o; Bahia, art. 281; Ceará, art. 185; Distrito Federal, art. 276; Espírito Santo, art. 98; Goiás, art. 170, I; Maranhão, art. 251, II; Piauí, art. 248, § 70; Mato Grosso, art. 233; Minas Gerais, art. 221, § único, III; Paraná, art. 215, II; Rio Grande do Norte, art. 155, § 4o; Rio Grande do Sul, art. 194; Rio de Janeiro, art. 33; Santa Catarina, art. 186, § único, III; e Tocantins, art. 121, § único, I(a)). Procura-se ainda proteger a "imagem social da mulher como mãe, trabalhadora e cidadã em igualdade de condições com o homem" (Mato Grosso do Sul, art. 254; Amapá, art. 330).

Esses tímidos avanços do constituinte estadual, entretanto, ficam sob a mira do Supremo Tribunal Federal na fiscalização meticulosa de eventual invasão dos domínios de

\footnotetext{
44 "É dever do Estado proteger e estimular as manifestações culturais dos diferentes grupos étnicos formadores da sociedade rio-grandense".
} 
competência dos outros entes federativos. Foi, assim, que declarou inconstitucional o Art. 13 da Constituição Estadual do Rio de Janeiro que enumerava, entre os direitos e garantias fundamentais, a gratuidade de sepultamento e dos procedimentos a ele pertinentes, para as pessoas que percebem até um salário mínimo, os desempregados e os reconhecidamente pobres. O constituinte estadual teria avançado sobre os serviços funerários, que se encontrariam no âmbito de competência municipal (art. 30, V). (BRASIL, 2003).

O pendor centralista do constitucionalismo brasileiro tem marcas em sua história. A desconfiança com os estados, vistos como guetos das oligarquias capazes de capturar a agenda nacional, a tomar-se a República Velha como exemplo, parece alimentar o pensamento contrário à maior liberdade e criação do constitucionalismo subnacional, mesmo no âmbito dos direitos fundamentais (ABRUCIO, 1998; DOLHNIKOFF, 2005; BARBOSA, 2014, p. 82). A jurisprudência do Supremo Tribunal Federal seria um tributário dessa orientação constitucional e federativa - ainda que, aqui, pareça uma contradição em termos ${ }^{45}$.

\section{CONSIDERAÇÕES FINAIS}

A autonomia constitucional é uma das características mais apontadas pela literatura para diferenciar uma federação de outras formas de Estado, especialmente as unitárias, as regionais e autonômicas. Entende-se por autonomia constitucional o poder que as unidades subnacionais possuem para elaborar sua própria Constituição. Trata-se, no entanto, de um poder limitado pela Constituição federal. Alguns Estados que se autoproclamam "federais" não reconhecem esse poder, abrindo espaços para discussão para sua natureza. Em regra, afirma-se que, embora deficientes nesse requisito, apresentam outras características que Ihes mantém na lista das federações, como, por exemplo, a participação nos processos deliberativos nacionais.

Mesmo entre os que preveem expressamente essa autonomia, há sistemas que parecem estabelecer uma faculdade aos unidades subnacionais, a exemplo da África do Sul, da

\footnotetext{
${ }^{45}$ A irrelevância das Constituições estaduais pode ainda ser produto no baixo envolvimento social na sua elaboração e nos processos de emenda, a refletir-se no reconhecimento daquelas Constituições como elemento de autoconstituição e autogoverno. A falta de um "momento constituinte" originário, decorrente de uma "fadiga" do processo federal que culminou com a Constituição de 1988 ou, pelo menos, de seu ofuscamento, uma vez que as Assembleias estaduais foram eleitas em 1989 para rapidamente elaborarem os textos constitucionais, pode ser apresentada como um dos fatores desmobilizantes. Assim também se pode dizer da invisibilidade do processo reformador das Constituições dos estados. Associem-se a isso a baixa presença dos discursos acadêmicos do constitucionalismo estadual e o apelo meramente secundário das normas constitucionais estaduais como parâmetros de controle de constitucionalidade e de suas diferenças para os cânones federais.
} 
Bósnia-Herzegovina, do Canadá, da Malásia e, em certa medida, da Rússia; e outros que, como o Brasil, obrigam a auto-organização constitucional de tais unidades. Essa maior ou menor liberdade deixada pela Constituição federal ao constituinte subnacional depende de alguns fatores, normalmente associados à história e cultura de um povo, resultando num documento subnacional maior ou menor, com ou sem muita criatividade constituinte.

O constitucionalismo subnacional, projetando nesses espaços os elementos que caracterizam o constitucionalismo nacional, com suas exigências de separação dos poderes e garantia de direitos fundamentais, tende a ser mais desenvolvido nos Estados federais e, dentre esses, especialmente naqueles onde há um espaço maior para a criação do constituinte subnacional.

Nos domínios dos direitos fundamentais, essas diferenças de tratamento constitucional também se refletem no catálogo de direitos, por acaso, existentes subnacionalmente. Há Constituições federais que apresentam uma declaração de direitos extensa. As unidades subnacionais ou silenciam a respeito da matéria ou cuidam de apenas reproduzir o texto federal. A ampliação do rol de direitos pode esbarrar, por vezes, na repartição de competências federativas realizada naquele texto, não podendo, portanto, inovar.

Nas Constituições federais, em que há uma declaração de direitos pouco extensa ou em que se admite a dualidade de proteção jusfundamental, costuma-se ter uma produção constitucional mais desenvolvida nas entidades subnacionais. Os Estados Unidos são o grande exemplo. As Constituições estaduais daquele país costumam ser bem mais detalhadas do que o texto federal e, na sua grande maioria, reconhecem direitos positivos, inclusive de cunho social, econômico e social, que são negados em nível federal. Essa é uma tendência verificável em outras federações como a alemã e que, materialmente, estende-se a temas como a proteção às minorias e ao meio ambiente. Em muitos casos, a inovação subnacional no campo dos direitos fundamentais se deve à criatividade do judiciário.

No Brasil, onde há um catálogo extenso de direitos fundamentais e um número alto de competências federais enumeradas, as Constituições estaduais não avançam muito no sistema de proteção jusfundamental. Algumas fazem referências genéricas à declaração federal; outras, nem isso. É certo, porém, que nos assuntos que se encontram na esfera de competência concorrente, como um número elevado de direitos sociais, econômicos e culturais, mais o direito ao meio ambiente equilibrado, há uma atenção e desenvolvimento maiores. Assim também, nalguns textos estaduais que fazem remissão à declaração de direitos da Constituição 
federal, vê-se uma preocupação com os direitos dos presos e o resguardo dos direitos civis e políticos.

A proteção da mulher contra discriminação e violência é um traço bem marcante do constitucionalismo subnacional brasileiro. Nalguns textos, aparece, inclusive, uma preocupação com seus direitos sexuais e reprodutivos, embora a interrupção da gravidez esteja circunscrita às hipóteses legalmente admitidas. A ênfase ao papel do afro-brasileiro e das comunidades indígenas na formação da identidade e cultura nacionais é outro elemento presente em quase todas as Constituições dos estados, assim como a previsão de sua proteção, inclusive por meio de ações afirmativas. Diversos grupos sociais minoritários como quilombolas, ciganos e ribeirinhos aparecem como sujeitos de proteção especial, embora em diferentes matizes e mesmo presenças nos textos estaduais. O que é discutível, todavia é o nível de eficácia dessas normas. No Brasil e em outros estados federais. A discussão é feita até mesmo no celeiro do constitucionalismo subnacional: os Estados Unidos. Há, no entanto, a ideia de que os desenvolvimentos temáticos sobre direitos fundamentais no âmbito estadual, ainda que portadores de algum déficit de eficácia, induzem o diálogo interinstitucional e federativo, reforçando-Ihes em dignidade e importância. Algo ainda incipiente no Brasil.

A história do federalismo brasileiro, marcada por uma desconfiança com os estados e um pendor centralista, dá um bom roteiro de compreensão sobre o baixo índice de liberdade do constituinte estadual e de sua capacidade inovadora, inclusive no campo dos direitos fundamentais. A jurisprudência do Supremo Tribunal Federal, resultante desse mesmo processo, tende a desestimular ainda mais o legislador dos estados a exercerem suas competências nas brechas de autonomia deixadas pelo constituinte federal.

\section{REFERÊNCIAS}

ABRUCIO, Fernando. Os Barões da Federação: Os Governadores e a Redemocratização Brasileira. São Paulo, Hucitec, 1998.

ÁFRICA DO SUL. Constitution of 1996 (Atualizada em 2005). Disponível em < http://bit.ly/1VPWx5R>. Acesso em: 15 mar. 2017. 
ÁFRICA DO SUL. Tribunal Constitucional. Certification of the Kwazulu-Natal Constitution (CCT15/96) [1996] ZACC 17; 1996 (11) BCLR 1419; 1996 (4) SA 1098 (6 September 1996). Disponível em: < https://goo.gl/2zt4mT>. Acesso em: 10 jan. 2018.

ALEMANHA. Lei Fundamental de Bonn. (Atualizada até janeiro 2011). Disponível em: <http://bit.ly/2qls7lz>. Acesso em: 15 mar. 2017.

ANDREU, Josep Maria C. La Sentencia del Tribunal Constitucional 31/2010, sobre el Estatuto de Autonomía de Cataluña y Su Significado para el Futuro del Estado Autonómico, sept. 2010. Disponível em: <https://goo.gl/KwQmVX>. Acesso em 12 jan. 2018.

ARAÚJO, Luiz Alberto D.; NUNES JÚNIOR, Vidal Serrano. Curso de Direito Constitucional. São Paulo: Saraiva, 2011.

ARGENTINA. Constitución de 1853 (Atualizada em 15/12/1994). Disponível em: <http://bit.ly/2eedveP>. Acesso em: 15 mar 2017.

AUSTRÁLIA. Constituição de 1900 (com emendas até 1977). Disponível em: <http://encurtador.com.br/rtCU3>. Acesso em 15/02/2017.

ÁUSTRIA. Constitution of 1920, Reinstated in 1945, with Amendments through 2013. Disponivel em: <http://bit.ly/2sYC7LZ>. Acesso em 15 mar. 2017.

BADÍA, Juan F. El Federalismo. Revista de estudios políticos, n. 206, p. 23-76, 1976.

BARBOSA, Rui. A velha Messalina. In BARBOSA Rui. Obras Seletas. v. II. São Paulo: Poeteiro Digital, 2014.

BÉLGICA. Constitution of 1831 (Atualizada em 05/2014). Disponível em: <http://bit.ly/2sZ4pGh>. Acesso em 15 mar. 2017.

BRASIL. Acre. Constituição Estadual 1989. Disponível em: <https://goo.gl/dcNyjm>. Acesso em: 12 jan. 2018. 
BRASIL. Alagoas. Constituição Estadual 1989. Disponível em: <https://goo.gl/7KGLwb>. Acesso em: 12 jan. 2018.

BRASIL. Amapá. Constituição Estadual 1991. Disponível em: <https://goo.gl/PDWJUR>. Acesso em: 12 jan. 2018.

BRASIL. Amazonas. Constituição Estadual 1989. Disponível em: <https://goo.gl/ui8dbQ>. Acesso em: 12 jan. 2018.

BRASIL. Bahia. Constituição Estadual 1989. Disponível em: <https://goo.gl/1kTyyQ>. Acesso em: 12 jan. 2018.

BRASIL. Ceará. Constituição Estadual 1989. Disponível em: <https://goo.gl/yvMUvZ>. Acesso em: 12 jan. 2018.

BRASIL. Constituição Federal de 1988 (Atualizada em 6/6/2017). Disponível em: <http://bit.ly/1eolror>. Acesso em 09 jun. 2017.

BRASIL. Distrito Federal. Lei Orgânica de 1993. Disponível em: <https://goo.gl/kkZkiJ>. Acesso em: 12 jan. 2018.

BRASIL. Espírito Santo. Constituição Estadual 1989. Disponível em: <https://goo.gl/zZyJWW>. Acesso em: 12 jan. 2018.

BRASIL. Goiás. Constituição Estadual 1989. Disponível em: <https://goo.gl/BuQJct>. Acesso em: 12 jan. 2018.

BRASIL. Maranhão. Constituição Estadual 1989. Disponível em: <https://goo.gl/VgmwNp>. Acesso em: 12 jan. 2018.

BRASIL. Mato Grosso do Sul. Constituição Estadual 1989. Disponível em: <https://goo.gl/KjaJT3>. Acesso em: 12 jan. 2018. 
BRASIL. Mato Grosso. Constituição Estadual 1989. Disponível em: <https://goo.gl/4w2gna>. Acesso em: 12 jan. 2018.

BRASIL. Minas Gerais. Constituição Estadual 1989. Disponível em: <https://goo.gl/WDAuVQ>. Acesso em: 12 jan. 2018.

BRASIL. Pará. Constituição Estadual 1989. Disponível em: <https://goo.gl/2Kh5oP>. Acesso em: 12 jan. 2018.

BRASIL. Paraíba. Constituição Estadual 1989. Disponível em: <https://goo.gl/LP7s24>. Acesso em: 12 jan. 2018.

BRASIL. Paraná. Constituição Estadual 1989. Disponível em: <https://goo.gl/yGJveM>. Acesso em: 12 jan. 2018.

BRASIL. Pernambuco. Constituição Estadual 1989. Disponível em: <https://goo.gl/DHqCdE>. Acesso em: 12 jan. 2018.

BRASIL. Piauí. Constituição Estadual 1989. Disponível em: <https://goo.gl/cQwVMf>. Acesso em: 12 jan. 2018.

BRASIL. Rio de Janeiro. Constituição Estadual 1989. Disponível em: <https://goo.gl/gKzRMn>. Acesso em: 12 jan. 2018.

BRASIL. Rio Grande do Norte. Constituição Estadual 1989. Disponível em: <https://goo.gl/3rfu59>. Acesso em: 12 jan. 2018.

BRASIL. Rio Grande do Sul. Constituição Estadual 1989. Disponível em: <https://goo.gl/u2aBLV>. Acesso em: 12 jan. 2018.

BRASIL. Rondônia. Constituição Estadual 1989. Disponível em: <https://goo.gl/x1Do3p>. Acesso em: 12 jan. 2018. 
BRASIL. Roraima. Constituição Estadual 1991. Disponível em: <https://goo.gl/iZ4Uiw>. Acesso em: 12 jan. 2018.

BRASIL. Santa Catarina. Constituição Estadual 1989. Disponível em: <https://goo.gl/LcRVk6>. Acesso em: 12 jan. 2018.

BRASIL. São Paulo. Constituição Estadual 1989. Disponível em: <https://goo.gl/Xx4NKs>. Acesso em: 12 jan. 2018.

BRASIL. Sergipe. Constituição Estadual 1989. Disponível em: <https://goo.gl/XppsZk>. Acesso em: 12 jan. 2018.

BRASIL. Tocantins. Constituição Estadual 1989. Disponível em: <https://goo.gl/1Cw3Lb>. Acesso em: 12 jan. 2018.

BRENNAN JR, William J. State Constitutions and the Protection of Individual Rights. Harvard Law Review, v. 90, n. 3, p. 489-504, 1977.

BULFER, Dan J. How California Got It Right: Mining In Re Marriage Cases for the Seeds of a Viable Federal Challenge to Same-Sex Marriage Bans. California Western International Law Journal, v. 41, n. 1, p. 49-92, 2010

BUßJÄGER, Peter. Sub-national Constitutions and the Federal Constitution in Austria. In BURGESS, Michael; TARR, G. Alan (eds). Constitutional Dynamics in Federal Systems. Montreal; Kingston: McGill-Queen's University Press, p. 88-106, 2012.

CANADÁ. Constituição de 1867 (com emenda de 1982). Disponível em: <http://encurtador.com.br/itQZ0>. Acesso em 15/02/2017.

CARNOTA, Walter F. La justicia constitucional en el constitucionalismo subnacional mexicano. Anuario iberoamericano de justicia constitucional, n. 20, p. 69-84, 2016. 
DELLEDONE, Giacomo; MARTINICO, Giuseppe. Handle with Care!: The Regional Charters and Italian Constitutionalism's 'Grey Zone'. European Constitutional Law Review, v. 5, n. 2, p. 218236, 2009.

DELLEDONNE, Giacomo. Speaking in Name of the Constituent Power: the Spanish Constitutional Court and the New Catalan Estatut. Perspectives on Federalism, v. 3, n. 1, p. 1-14, 2011.

DELLEDONNE, Giacomo; MARTINICO, Giuseppe. Legal Conflict and Subnational Constitutionalism, EUI Working Papers Law 2011/03. Disponível em: <https://goo.gl/KCqUsR>. Acesso em 5 mar. 2018.

DINAN, John. Patterns and Developments in Subnational Constitutional Amendment Processes, Paper 2009. disponível em: <https://goo.gl/uiUyci>. Acesso em 15 fev. 2018.

DOLHNIKOFF, Miriam. O pacto imperial: origens do federalismo no Brasil. Rio de Janeiro: Globo Livros, 2005.

EDER, Christina; VATTER, Adrian; FREITAG, Markus. Institutional design and the use of direct democracy: Evidence from the German Länder. West European Politics, v. 32, n. 3, p. 611-633, 2009.

ELAZAR, Daniel J. Exploring Federalism. Tuscaloosa: University of Alabama, 1991.

ELAZAR, Daniel J. State Constitutional Design in the United States and other Federal Systems. Publius, v. 12, p. 1-10, 1982.

EMIRADOS ÁRABES UNIDOS. Constitution of 1971 with Amendments through 2004. disponível em < http://bit.ly/2sYTKLQ>. Acesso em: 15 mar. 2017.

ESPANHA. Tribunal Constitucional. Sentencia n. 247/2007, de 12 de dezembro. Disponível em: < https://goo.gl/XFupkj>. Acesso em 13 jan. 2018 
ESPANHA. Tribunal Constitucional. Sentencia n. 31/2010. Disponível em: < https://goo.gl/SU96Zm>. Acesso em 13 jan. 2018.

ESTADOS UNIDOS. Constitution of 1787 (Atualizada em 1992). Disponível em <http://bit.ly/2lvunOp>. Acesso em: 15 mar. 2017.

ESTADOS UNIDOS. Suprema Corte da Califórnia. People v. Anderson, 6 Cal. 3d. 628 (1972). Disponível em: < https://goo.gl/F6QAEj>. Acesso em 13 jan 2018.

ESTADOS UNIDOS. Suprema Corte. DeShaney v Winnebago County Department of Social Services. 489 U.S. 189 (1989). Disponível em: < https://goo.gl/FDvZUl>. Acesso em 11 fev. 2108. ESTADOS UNIDOS. Suprema Corte. New State Ice Co. v. Liebmann, 285 U.S. 262, 311 (1932). (voto dissidente do Justice Brandeis). Disponível em: <https://goo.gl/ctTexn>. Acesso em 17 jan. 2018

ESTADOS UNIDOS. Suprema Corte. San Antonio Independent School District v Rodriguez. 411 US, 1, (1973). Disponível em: <https://goo.gl/ZV5C9S>. Acesso em 11 fev. 2018.

FAVOREU, Louis et al. Droit Constitutionnel. 9.ed. Paris: Dalloz, 2006.

FEELEY, Malcolm; RUBIN, Edward L. Federalism: Political Identity and Tragic Compromise. Ann Arbor: The University of Michigan Press, 2008.

FERRARI, Regina Maria Macedo N. Controle da Constitucionalidade das Leis Municipais. 2a ed. São Paulo: Editora Revista dos Tribunais, 1994.

FRIEDMAN, Lawrence. State Constitutions in Historical Perspective. Annals of the American Academy of Political and Social Science, v. 496, p. 33-43, 1988.

GAMPER, Anna. Constitutional Courts, Constitutional Interpretation, and Subnational Constitutionalism. Perspectives on Federalism, v. 6, n. 2, p. 24-44, 2014. 
GARDNER, James A. In Search of Subnational Constitutituionalism. Buffalo Legal Studies Research Paper n. 2007-016. Disponível em: < https://goo.gl/14qjjF>. Acesso em: 15 jan. 2018.

GARZA, José María S. Strengthening State Constitutionalism from the Federal Constitution: The Case of Mexico. Perspectives on Federalism, v. 6, n. 2, p. 74-88, 2014

GINSBURG, Tom; POSNER, Eric A. Subconstitutionalism. The Chicago Working Paper Series 2010. Disponível em: < https://goo.gl/4LqfHF>. Acesso em 15 jan. 2018.

GONZÁLEZ, Juan Marcos G. United Mexican States. In TARR, G. Alan; KINCAID, John (eds.). Constitutional Origins, Structure, and Change in Federal Countries. Montreal: McGill-Queens University Press, p. 208-238, 2005.

GUNLICKS, Arthur B. Land Constitutions in Germany. Publius: The Journal of Federalism, v. XXVIII, n. 4, p. 105-125, 1998.

HERDEGEN, Mathias. Strukturen und Institute des Verfassungsrechts der Länder. In ISENSEE, Josef; KIRCHHOF, Paul (Hrsg.) Handbuch des Staatsrechts. 3. Aufl. Band. 6 (Bundestaat). Heidelberg: C.F. Müller, p. 271-316, 2008.

HERSHKOFF, Helen. Positive Rights and State Constitutions: The Limits of Federal Rationality Review. Harvard Law Review, v. 112, n. 6, p. 1131-1196, 1999

HORTA, Raul Machado. Direito Constitucional. 5a ed. Atualizada por Juliana Campos Horta Belo Horizonte: Del Rey, 2010.

ÍNDIA. Constitution of 1950 (Atualizada em 11/2015). Disponível em <http://bit.ly/1YllHt2>. Acesso em: 15 mar. 2017.

IRAQUE. Constitution of 2005. Disponível em:< http://bit.ly/1e1jJsa >. Acesso em: 15 mar. 2017. ITÁLIA. Tribunal Constitucional. Sentenza 365/2007. Disponível em: <https://goo.gl/rw8No4>. Acesso em 13 jan. 2018. 
KARLHOFER, Ferdinand. Sub-national Constitutionalism in Austria: a Historical Institutionalist Perspective. Perspectives on Federalism, v. 7, n. 1, p. 57-84, 2015.

KEYSSAR, Alexander. The Right to Vote: The Contested History of Democracy in the United States. New York: Basic Books, 2000.

LEVINSON, Sanford. Courts as Participants in "Dialogue": A View from American States. Kansas Law Review, v. 59, p. 791-831, 2011.

LORENZ, Astrid; REUTTER, Werner. Subconstitutionalism in a multilayered system. A comparative analysis of constitutional politics in the German Länder. Perspectives on Federalism, v. 4, n. 2, p. 148-170, 2012.

LORENZ, Astrid; REUTTER, Werner. Subconstitutionalism in a multilayered system. A comparative analysis of constitutional politics in the German Länder. Perspectives on Federalism, v. 4, n. 2, p. 148-170, 2012.

MALÁSIA. Constitution of 1957 (status 2015). Disponível em:<http://bit.ly/1WI4PSh>. Acesso em 15 mar. 2017.

MARSHFIELD, Jonathan L. Authorizing Subnational Constitutions in Transitional Federal States: South Africa, Democracy, and the KwaZuluNatal. Vanderbilt Journal of Transnational Law, v. 41, p. 585-648, 2008.

MARSHFIELD, Jonathan L. Models of Subnational Constitutionalism. Penn State Law Review, v. 115, n. 4, p. 1151-1198, 2011

MAY, Janice C. The Constitutional Initiative: A Threat to Rights?. In FRIEDELBAUM, Stanley H. (ed). Human Rights in the States: New Directions in Constitutional Policymaking. Westport: Greenwood Press, p. 163-184, 1988. 
McDONAUGH, Eileen; PRICE, H. Douglas. Woman Suffrage in the Progressive Era: Patterns of Opposition and Support in Referenda Voting, 1910-1918. American Political Science Review, v. 79, n. 2, p. 415-435, 1985.

MEIRELLES, Hely Lopes. Direito Municipal Brasileiro. 13a ed. São Paulo: Malheiros, 2001.

MÉXICO. Constitución de 1917 (Atualizada em 24/02/2017). Disponível em < http://bit.ly/2mKDwHf>. Acesso em: 15 mar. 2017.

PAQUISTÃO. Constitution of 1973 (Atualizada em 7/1/2015. Disponível em: <http://bit.ly/2sYF1AE>. Acesso em: 15 mar. 2017.

PARIS, Michael. Framing Equal Opportunity: Law and the Politics of School Finance Reform. Stanford: Stanford University Press, 2009.

PAS Wouter. A Dynamic Federalism Built on Static Principles: The Case of Belgium. In TARR, G. Alan; WILLIAMS, Robert F.; MARKO, Josef (eds.). Federalism, Subnational Constitutions, and Minority Rights. Westport: Praeger, p. 157-175, 2004.

POPE, James G. An Approach to State Constitutional Interpretation. Rutgers Law Journal, v. 24, p. 985-1008, 1993.

POPELIER, Patricia. The Need for Sub-National Constitutions in Federal Theory and Practice. The Belgian Case. Perspectives on Federalism, v. 4, n. 2, 2012, p. 36-58, 2012.

PRÉLOT, Michel Institutions Politiques et Droit Constitutionnel. 5. ed. Paris: Dalloz, París, 1972. REGASSA, Tsegaye. Sub-National Constitutional in Ethiopia; Towards Entrenching Constitutionalism at State Level. Mizan Law Review, v. 3, n. 1, p. 32-69, 2009.

RÚSSIA. Constitution of 1993 (com emendas até 2008). Disponível em:<http://bit.ly/2rUA1h6>. Acesso em: 15 mar. 2017. 
SAMPAIO, José Adércio Leite. A Constituição Reinventada pela Jurisdição Constitucional. Belo Horizonte: Del Rey, 2002.

SAMPAIO, José Adércio Leite. Direitos Fundamentais como Trufas da Maioria. RECHTD. Revista de Estudos Constitucionais, Hermenêutica e Teoria do Direito , v. 7, p. 226-234, 2015.

SAMPAIO, José Adércio Leite. Teoria da Constituição e dos Direitos Fundamentais. Belo Horizonte: Del Rey, 2013.

SAUNDERS, Cheryl. The Relationship Between National and Subnational Constitutions. In CARPENTER, Gretchen (ed). Subnational Constitutional Governance. Johannesburg: Konrad Adenauer Stiftung, p. 23-35, 1999. Disponível em: <https://goo.gl/MTJn8i>. Acesso em 13 jan 2018.

SAUNDERS, Cheryl. The Constitutional Credentials of State. Melbourne Legal Studies Research Paper No. 621, p. 1-7. Disponível em: < https://goo.gl/zgc2v7>. Acesso em 08 mar 2018.

SAVAGE, Robert L. Diffusion Research Traditions and the Spread of Policy Innovation in a Federal System. Publius The Journal of Federalism, v.15, n. 4, p. 1-28, 1985.

SCHAPIRO, Robert A. Polyphonic Federalism: Toward the Protection of Fundamental Rights. Chicago; London: University of Chicago Press, 2009.

SCHEIBER, Harry N. Foreword: The Direct Ballot and State Constitutionalism. Rutgers Law Journal, v. 28, p. 787-823, 1996.

SHATZ, Steven F.; RIVKIND, Nina. The California death penalty scheme: requiem for Furman. New York University LawReview., v. 72, p. 1283-1343, 1997.

STEPAN, Alfred. Modern Multinational Democracies: Transcending a Gellnerian Oxymoron. In HALL, John A (ed). The State of the Nation: Ernest Gellner and the Theory of Nationalism. New York: Cambridge University Press, p. 219-242, 1998. 
SUDÃO DO SUL. Constituição de 2011. Disponível em: <http://encurtador.com.br/yAG67> Acesso em 11/04/2017.

SUDÃO. Constitution of 2005. Disponível em <http://bit.ly/2sOBggH>. Acesso em: 15 mar. 2017 SUIÇA. Constituição de 1999 com emendas até 2016. Disponível em:<http://encurtador.com.br/bjKS7>. Acesso em 11/03/2017

TARR, G. Alan. Explaining Sub-national Constitutional Space. Penn State Law Review, v. 115, n. 4, p. 1133-1149, 2011

TARR, G. Alan. Taking Subnational Constitutions Seriously: Explaining Change and Development in the Evolution of Federal and QuasiFederal States, 2008. Disponível em: <https://goo.gl/tkUNGP>. Acesso em 18 fev. 2018.

TARR, G. Alan. Federalism, Subnational Constitutionalism, and the Protection of Minority Rights in the United States, July 2001. Disponível em: < https://goo.gl/4D2tRW>. Acesso em 18 fev. 2018.

THOMPSON JR, Barton H. Environmental Policy and the State Constitution: The Role for Substantive Policy Guidance. Rutgers Law Journal, v. 27, p. 863-1253, 1996.

TRIBE, Laurence H. Unravelling National League of Cities: The New Federalism and Affirmative Rights to Essential Government Services. Harvard Law Review, v. 90, n. 6, p. 1065-1104, 1977.

VENEZUELA. Constitución de 1999 (Atualizada em 19/02/2009). Disponível em <http://bit.ly/1P5sShH>. Acesso em: 15 mar. 2017.

VERSTEEG, Mila; ZACKIN, Emily. A Excepcionalidade Constitucional Americana Revisitada. Novos Estudos Jurídicos, v. 19, n. 3, p. 695-754, 2014.

VERSTEEG, Mila; ZACKIN, Emily. A Excepcionalidade Constitucional Americana Revisitada. Novos Estudos Jurídicos, v. 19, n. 3, p. 695-754, 2014. 
WATTS, Ronald L. States, Provinces, Länder, and Cantons: International Variety Among Subnational Constitutions. In Subnational Constitutional Governance. Johannesburg: Konrad Adenauer Stiftung, p. 11-21, 1999. Disponível em: <https://goo.gl/MTJn8i >. Acesso 15 fev. 2018.

WEISS, Norman. The Protection of Minorities in a Federal State: The Case of Germany. In TARR, G. Alan; WILLIAMS, Robert F.; MARKO, Josef (eds.). Federalism, Subnational Constitutions, and Minority Rights. Westport; London: Praeger, 2004.

WILLIAMS, Robert F.; TARR, G. Alan. Subnational Constitutional Space: A View from the States, Provinces, Regions, Länder, and Cantons. In TARR, G. Alan; WILLIAMS, Robert F.; MARKO, Josef (eds.). Federalism, Subnational Constitutions, and Minority Rights. Westport; London: Praeger, p. 3-24, 2004.

ZACKIN, Emily. Looking for Rights in All the Wrong Places: Why State Constitutions Contain America's Positive Rights. Princeton: Princeton University Press, 2013.

ZACKIN, Emily. Looking for Rights in All the Wrong Places: Why State Constitutions Contain America's Positive Rights. Princeton: Princeton University Press, 2013.

Trabalho enviado em 13 de junho de 2018

Aceito em 25 de agosto de 2018 